\title{
BLACK CARBON AEROSOL AT THE BACKGROUND SITE IN THE COASTAL ZONE OF THE BALTIC SEA
}

\author{
J. Andriejauskienè ${ }^{a}$, V. Ulevičius ${ }^{a}$, M. Bizjak ${ }^{b}$, N. Špirkauskaitė ${ }^{a}$, and \\ S. Byčenkiené ${ }^{\mathrm{a}}$ \\ a Institute of Physics, Savanoriu 231, LT-02300 Vilnius, Lithuania \\ E-mail: jelena.andriejauskiene@email.lt \\ ${ }^{\mathrm{b}}$ University of Ljubljana, Kongresni trg. 12, SI-1000 Ljubljana, Slovenia
}

Received 10 March 2008; accepted 9 June 2008

\begin{abstract}
Carbon particulate matter constitutes an important portion of the atmospheric aerosol and directly participates in the formation of the Earth's radiation balance by influencing the global and regional climate. Continuous data (March, April, 2002) of 20-minute concentrations of airborne black carbon (BC) particles at the Preila Environmental Pollution Research Station $\left(55^{\circ} 20^{\prime} \mathrm{N}, 21^{\circ} 00^{\prime} \mathrm{E}\right)$ have been used for the investigation of diurnal and weekday variation as well as the different air mass influence on $\mathrm{BC}$ transport. The measurement of $\mathrm{BC}$ mass concentration with the Aethalometer ${ }^{\mathrm{TM}}$, Model AE40 Spectrum, manufactured by Optotek, Slovenia was carried out. The origin of an air mass was detected by using air mass backward trajectories calculated by the Hybrid Single-Particle Lagrangian Integrated Trajectories (HYSPLIT) model. Approximately 73\% of $\mathrm{BC}$ measured concentrations were found in the range of a low value mode centered at $\sim 0-1000 \mathrm{ng} \mathrm{m}^{-3}$. The remaining concentrations were in a high-concentration mode at $\sim 1000-3000 \mathrm{ng} \mathrm{m}^{-3}$, probably indicating a direct impact of emissions from combustion activities. BC concentration in various air masses over that period varied from the average value of approximately $140 \mathrm{ng} \mathrm{m}^{-3}$ to the maximum value of $2410 \mathrm{ng} \mathrm{m}^{-3}$. The highest $\mathrm{BC}$ concentrations were associated with the prevailing southern transport air masses. Simultaneously, the daily concentration variation of black carbon and $\mathrm{SO}_{2}, \mathrm{NO}_{2}, \mathrm{O}_{3}$ was measured and analysed. Total aerosol concentrations and size distributions were measured as well. The aerosol size distribution was plotted as contour plots for each day (as a function of time). Most studies were focused on the BC aerosol particle size distribution and modal aerosol concentration. For each event, the growth rate was calculated graphically from the contour plots ("banana-plots") and was analysed for the possible nucleation events. Some aerosol measurements were carried out at an urban site in order to evaluate the $\mathrm{BC}$ concentration of the freshly emitted traffic aerosols.
\end{abstract}

Keywords: black carbon aerosol, mass concentration, size distribution, variations, air mass backward trajectories

PACS: 92.60.Mt, 92.10.Lq, 92.20.Bk

\section{Introduction}

Carbon particulate matter constitutes an important portion of the atmospheric aerosol and directly participates in the formation of the Earth's radiation balance by absorbing and / or scattering solar radiation and influencing the global and regional climate $[1,2]$. Carbonaceous aerosols are the largest contributor to the fine particle burden in the atmosphere of urban and industrial regions [3-6]. As turned out during recent years, the aerosol fine mode of pollutants is causing health problems due to their penetration into the human organism [7]. Carbonaceous particles are composed of two main fractions: organic carbon (OC) and black carbon (BC) (or elemental carbon (EC)). In the atmosphere, black carbon occurs as a mixture of graphite-like particles and light-absorbing organic matter. Major sources of $\mathrm{BC}$ are the burning of diesel fuel, coal, jet fuel, natural gas, and biomass. $\mathrm{BC}$ can be removed from the atmosphere by dry deposition and rainout of aerosol and has a lifetime in the atmosphere of the order of several days to a week or two, depending on meteorology [1]. It is known that $\mathrm{BC}$ plays an important role in atmospheric chemistry because of its catalytic properties. Furthermore, the surface of carbonaceous aerosol can be a site for the catalytic oxidation of sulphur dioxide to sulphate and for the destruction of ozone [8]. For example, over the sea at night the formation of new particles due to specific reactions, leading to the formation of organic compounds, is observed [9]. The organic film formed on the surface of black carbon aerosol diminishes hygroscopic possibilities and this outer monolayer minimizes its participation in atmospheric chemistry. 
Particulate-phase pollutants emitted by motor vehicles (especially diesel vehicles) mostly consist of carbonaceous aerosol, with its two components - elemental carbon (also referred to as black carbon, sometimes also soot) and organic carbon (OC) [10]. The $\mathrm{BC}$ component does not consist of chunks of highly structured pure graphite, but rather is a more complex three-dimensional array of carbon with small amounts of other elements [11].

Although concentrations of $\mathrm{BC}$ are determined permanently at many locations worldwide, the major measurements are carried out in urban areas [12]. These data are primarily important for emission strength measurements and air quality studies. However, more global effects of $\mathrm{BC}$ aerosols can be better estimated in rural and remote regions, especially at coastal sites where clean air masses arrive from oceans or seas $[13,14]$. Therefore, the investigation of the relationship among the black carbon, aerosol mass concentration, and aerosol particles with different size number concentration in the air masses after long-range transport is important as well.

The main objectives of the study were: (i) to determine the difference between the $\mathrm{BC}$ concentration distribution in polluted (continental) and clean (marine) air masses at the background site; (ii) to investigate the $\mathrm{BC}$ concentration and aerosol size spectrum during new aerosol particle formation episodes; (iii) to estimate the distribution of the size of "fresh" black carbon aerosols of traffic exhausts in real time.

\section{Experimental technique}

\subsection{Measurement site and technique}

Continuous measurements of $\mathrm{BC}$, sulphur dioxide $\left(\mathrm{SO}_{2}\right)$, nitrogen dioxide $\left(\mathrm{NO}_{2}\right)$, and ozone $\left(\mathrm{O}_{3}\right)$ were performed at the Preila background station, which is located in the western part of Lithuania on the coast of the Baltic Sea, on the Curonian Spit $\left(55^{\circ} 20^{\prime} \mathrm{N}, 21^{\circ} 00^{\prime} \mathrm{E}\right.$, $5 \mathrm{~m}$ a.s. 1.). The station is far from substantial local sources of airborne pollutants and can thus be characterized as a regionally representative background area of Lithuania [15].

A Magee Scientific Company Aethalometer ${ }^{\mathrm{TM}}$, Model AE40 Spectrum, manufactured by Optotek, Slovenia was deployed at the site and provided real-time, continuous measurement of $\mathrm{BC}$ mass concentration. The instrument was operated with a 20-minute time base round the clock with a flow rate of about $31 \mathrm{~min}^{-1}$. The aethalometer uses an optical source with different solidstate light emission diodes (LED). These sources are activated sequentially to illuminate the aerosol sample at seven discrete wavelengths during each time cycle. In this way, the optical attenuation at seven points across the spectrum from ultraviolet to near-infrared was determined. This approach is based on the fact that at these wavelengths no other species has such strong absorption, and the optical attenuation measurement can be reasonably interpreted in terms of black carbon mass $[16,17]$. The rate of attenuation is proportional to the increase of optically absorbing material on the filter, which is proportional to the concentration of the absorbing BC in the sampled air flow. Black carbon has a broad absorption spectrum, which is inversely proportional to the wavelength of the incident light. The absorption of longer wavelengths of light dominates in black carbon which is associated with a graphitic form of carbon. Some other particulate carbonaceous species can also absorb shorter wavelengths of the incident light. The optical transmission of carbonaceous aerosol particles is measured sequentially at seven wavelengths $(370,450,520,590,660,880$, and $950 \mathrm{~nm})$. The concentration of black carbon corresponds to the $880 \mathrm{~nm}$ wavelength.

The aerosol particle counts were measured simultaneously with a LAS-15A optical particle counter (0.3$10 \mu \mathrm{m})$, and the aerosol particle number concentration and size distribution in the $10-200 \mathrm{~nm}$ size range were measured using the differential mobility particle sizer (ELAS-5Mc). Both devices have been designed in the Environmental Physics and Chemistry Laboratory of the Institute of Physics, Lithuania. More information can be found in [18].

The $\mathrm{O}_{3}$ concentration was measured continuously using the commercial UV absorption ozone analyzer $\mathrm{O}_{3} 41 \mathrm{M}$, Environment S.A. The precision of measurements was $2 \mu \mathrm{g} \mathrm{m}^{-3}$. The analyzer was calibrated against the standard reference UV photometer SRP17 at Czech Hydrometeorological Institute. More information about ozone concentration measurements at the station is presented in [19]. The hourly mean ozone data are used in this paper.

Sulphur dioxide was measured using the ion chromatography method with the lower limit of determination of $0.02 \mu \mathrm{gS} \mathrm{m}^{-3}$ and nitrogen dioxide by the spectrophotometry method with the lower limit of determination of $0.08 \mu \mathrm{gN} \mathrm{m}^{-3}$. More detailed information concerning sampling and analytical methods is presented in [20]. 


\subsection{Principle of an optical absorption method}

To determine the concentration ratios of black carbon and other admixtures, an optical absorption method using the aethalometer was applied [21]. The intensity decrease of the light beam having passed through the sample (collected on the fibre filter), which is linearly proportional to the black carbon amount on the filter, is measured.

The optical absorption $(O A)$ is expressed as

$$
O A=100 \ln \frac{I_{0}}{I},
$$

where $I_{0}$ is the intensity of the light having passed through the part of the filter without depositions and $I$ is the intensity of the light having passed through the part of the filter with depositions. The factor 100 is taken for the numerical convenience (the definition without this factor would mean the optical density transmission). By carrying out measurements in the white light using these units, we obtain hardly observable $O A$, the value of which is equal to 1 (the difference between "depositions" and "blank" is only $1 \%$ ), while the $O A$ value of 100 corresponds to the dark grey aerosol point.

The measurement result depends on the light wavelength, at which the measured particle is expected to be smaller than the wavelength. The light absorption using the wide band absorber (e.g., graphite carbon) is inversely proportional to the used light wavelength. For the mass $m$ of black carbon in a sample, the optical absorption at the fixed wavelength $\lambda$ is calculated as follows:

$$
O A(\lambda)=\sigma(1 / \lambda) m,
$$

where $m$ is the black carbon mass, $\sigma(1 / \lambda)$ is the optical absorption cross-section depending on the wavelength $\lambda$. The latter is called a specific absorption.

The specific absorption measured in $\mathrm{m}^{2} / \mathrm{g}$ is not the physical constant, but depends on the wavelength.

The optical intensity function of the measured matter depends on the wavelength. The intensity of the light having passed through the blank part of the filter is calculated as

$$
I_{0}(\lambda)=I_{\mathrm{L}}(\lambda) F(\lambda) C(\lambda) D(\lambda),
$$

where $I_{\mathrm{L}}(\lambda)$ is the intensity of the light source emission, $F(\lambda)$ is the optical transmission, $C(\lambda)$ is the function of spectral transmission through all other components, and $D(\lambda)$ is the detector spectral response function.
The total intensity of the light transmitted through aerosol deposition precipitate on the filter, using the same light source and detector, is

$$
I=I_{0} \exp ^{-A(\lambda)},
$$

and absorption is expressed by equation

$$
O A(\lambda)=k(1 / \lambda) m,
$$

where $m$ is the black carbon mass, the optical absorption of which is inversely proportional to the wavelength. $k$ is coefficient of this proportionality, defined as the specific absorption.

The logarithmic ratio of $I$ to $I_{0}$ (Eq. (4)), expressing the optical absorption, is proportional to the absorbing black carbon mass, when the wavelength depends on the optical components and the detector being weighted by the $1 / \lambda$ function.

Thus, we can state that the linear dependence on the absorbing material mass is characteristic of the particular optical absorption. This assumption is valid under the following conditions:

- particles are significantly smaller than the wavelength parameter $2 \pi \lambda$;

- the absorbing material amount in the sample is insufficiently large to cause saturation;

- the aerosol particle insertion into a deep, optically scattered fibre matrix must eliminate reduction of any optical transmission in the filter by optically scanning particles and makes measurements sensitive only to absorption.

These conditions are satisfied when the sample of environment aerosol particles is collected from quartz fibre filters, and the optical absorption is limited to 150 and less. The proportionality coefficient is a specific absorber $(O A / m)$. From Eq. (4) we obtain

$$
\sigma(1 / \lambda)=O A / m=100 k(1 / \lambda) .
$$

\section{Results and discussions}

\subsection{Diurnal variation of $B C$ concentration}

The aethalometer was in a continuous operation from 4 March to 29 April 2002. The total number of 20minute sample periods was about 4000 . Approximately $73 \%$ of $\mathrm{BC}$ concentrations were found in the range of a low value mode centred at $\sim 0-1000 \mathrm{ng} \mathrm{m}^{-3}$. The remaining measurements were in a high-concentration mode at $\sim 1000-3000 \mathrm{ng} \mathrm{m}^{-3}$, probably indicating a direct impact of emissions from combustion activities. 


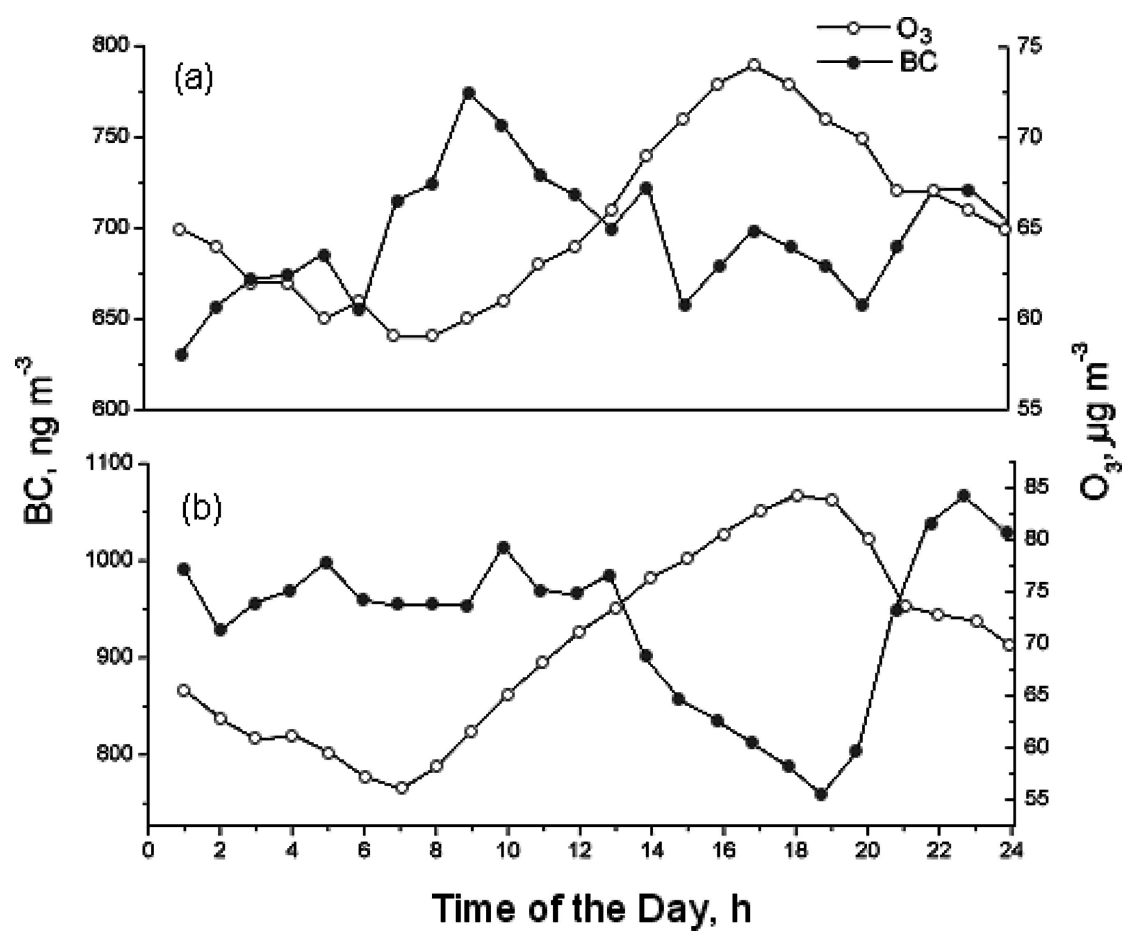

Fig. 1. Diurnal variation of black carbon and ozone concentration: (a) March, (b) April.

After certain grouping and averaging, daily variations in the diurnal pattern smoothen out giving the average diurnal picture (Fig. 1). Figure 1 shows the diurnal variation of black carbon aerosol and ozone concentrations over Preila. As expected, in March $\mathrm{BC}$ and $\mathrm{O}_{3}$ concentrations were lower than in April. The average black carbon concentration during March-April were 720 and $960 \mathrm{ng} \mathrm{m}^{-3}$, respectively.

Average hourly variations in $\mathrm{BC}$ concentrations in March showed a large peak during morning hours from 8 to 11 a.m., the lower peaks were observed from 4 to 7 p.m. and from 10 p.m. to 12 a.m. High values of black carbon concentration in the morning evidently could be interpreted as the effect of vertical mixing processes after breakup of the nighttime stable layer as well as the advection of air masses from urban regions where traffic exhausts in the morning and evening increased. Relatively low values of the $\mathrm{BC}$ concentration in the afternoon were attributed to the dispersion of aerosols due to the increase in the boundary layer height. Analysis of the $\mathrm{BC}$ diurnal concentration variation in April showed the opposite situation when the lowest BC concentrations were observed from 6 to 8 p.m. The diurnal variation was not as pronounced as in March. It can be related to the background site location. There is a gradual reduction of $\mathrm{BC}$ from 1 to 7 p.m. and a sharp peak occurs between 9 p.m. and 12 a.m. This could be caused by the transport of air mass from distant urban areas. Ozone concentrations varied from 58 to $84 \mu \mathrm{g} \mathrm{m}^{-3}$ and started increasing gradually after sunrise, reaching the maximum value in the evening and decreasing gradually thereafter. The analysis of data shows a statistically significant negative correlation between the ozone and black carbon diurnal variation indicating ozone depletion by surface reactions on $\mathrm{BC}$ particles. The negative correlation ranged from -0.30 to -0.55 .

Depending on the reaction mechanisms and reaction probabilities, soot may significantly influence the tropospheric trace gas chemistry by its surface reactions. If an ozone molecule collides with the active site on the surface of a carbon sample, one of its oxygen atoms gets adsorbed, while the resultant oxygen molecule is lib-

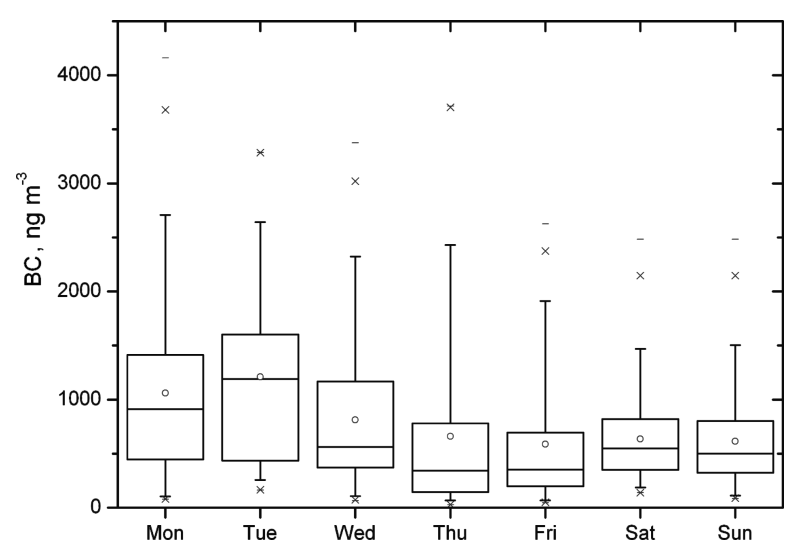

Fig. 2. Weekday variations of black carbon concentration over the study area. Box covers interquartile range between 25 th and 75 th percentiles. 
erated. The adsorbed oxygen atom can then combine with another adsorbed oxygen atom to form molecular oxygen. This catalytic reaction causes dramatic ozone depletion in the atmosphere [22].

\subsection{Weekly patterns of BC concentration}

To investigate the $\mathrm{BC}$ concentration distribution on the weekdays, concentrations of nine Mondays, eight Tuesdays, eight Wednesdays, eight Thursdays, eight Fridays, eight Saturdays, and eight Sundays were averaged. Figure 2 illustrates the day-of-week distribution of the data for each weekday lined up in order. As can be seen, the daily mean $\mathrm{BC}$ concentration decreases gradually from Tuesday to Friday with a little increase on Saturday and Sunday, and on Monday an increase begins. BC concentrations during the weekend (Friday, Saturday, and Sunday) decrease due to reduced human activities compared to working days. Daily variations of $\mathrm{BC}$ concentrations were found to be in the range of 1460-2710 $\mathrm{ng} \mathrm{m}^{-3}$ over the study area (Fig. 2). The lowest concentrations in the 95th percentile occurred on Saturday $\left(1460 \mathrm{ng} \mathrm{m}^{-3}\right.$ ), following the rise in the concentration from Sunday to Tuesday. A significant reduction in $\mathrm{BC}$ values observed during weekends compared to weekdays may be explained by considering the transport time of aerosols from urban areas. The lower concentration on Monday than on Tuesday can represent lower BC emissions on Sunday in the pollution source regions. The higher $\mathrm{BC}$ concentrations observed

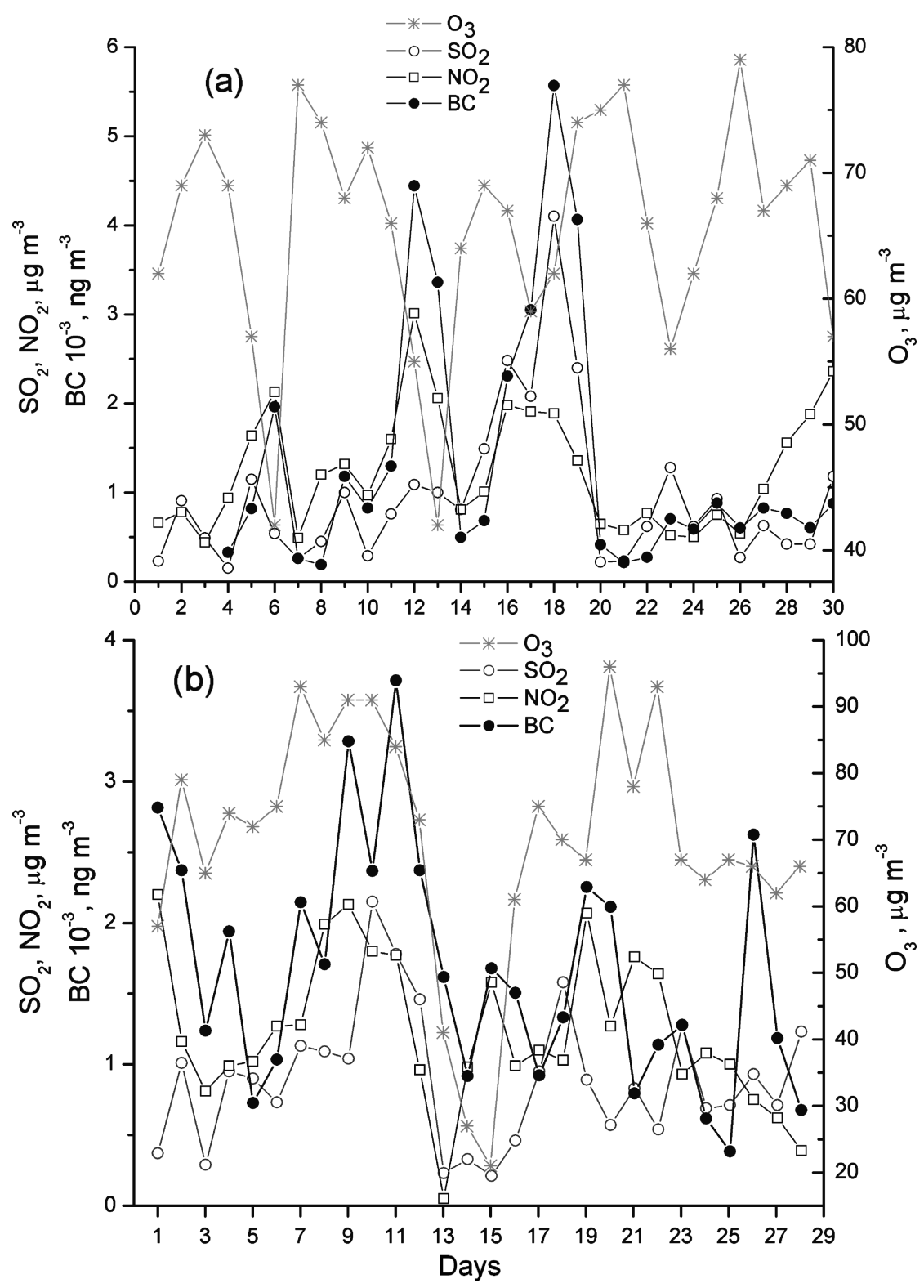

Fig. 3. Average diurnal $\mathrm{BC}, \mathrm{O}_{3}, \mathrm{NO}_{2}$, and $\mathrm{SO}_{2}$ concentrations: (a) March, (b) April. 
on Tuesday to Friday can be attributed to the decreased traffic intensity and lower industry activity on weekends.

\subsection{Courses of $B C$ and trace gas concentration}

The daily variations of mean concentrations of black carbon, atmospheric gases $\mathrm{NO}_{2}, \mathrm{SO}_{2}$, and $\mathrm{O}_{3}$ during the investigation period are shown in Fig. 3. BC concentration variation indicates similar courses of $\mathrm{NO}_{2}$ and $\mathrm{SO}_{2}$. Data analysis showed that courses of sulphur dioxide concentration and nitrogen dioxide concentration are poorly correlated. It has been found that the correlation between black carbon and $\mathrm{SO}_{2}$ as well as with $\mathrm{NO}_{2}$ is positive with a correlation coefficient $R=0.44$ and $R=0.43$, respectively (samples number $n=116$ ). The daily March and April ozone mean values ranged from 17.5 to $98.0 \mu \mathrm{g} \mathrm{m}^{-3}$ and 14.0 to $93.0 \mu \mathrm{g} \mathrm{m}^{-3}$, respectively. The data clearly show the daily variation in ozone concentration with a minimum at around 7 a.m. in the morning and a maximum at 2 p.m. in the afternoon. According to the mean hourly values, the ozone concentration was lower in the morning at 7-9 a.m., and in the evening after 10 p.m. The slope between black carbon aerosols and tropospheric ozone has been estimated to be -0.1 and -0.5 , implying that every $1 \mu \mathrm{g} \mathrm{m}^{-3}$ increase in black carbon aerosol mass concentration causes a reduction by 0.1 and $0.5 \mu \mathrm{g} \mathrm{m}^{-3}$ of surface ozone in March and April, respectively (Fig. 3). This reduction can be partly due to the aggregate structure of soot particles, which provide a large specific surface area for heterogeneous interactions with reactive trace gases such as ozone [22].

\subsection{BC concentrations in different air masses}

Fine-size and chemically inert BC particles can be transported over long distances $[9,11]$. Thus, significant BC concentrations could be observed over larger distances downwind of the potential source regions. To investigate the influence of the air mass having passed over regions situated about 200-300 km from the Preila site on the BC mass concentration, each BC sample was categorized by air mass 24 -hour backward trajectories. Figure 4 shows the trajectory frequency distribution by the transport direction of air masses reaching the Preila site during the study. Air mass backward trajectories at heights of 20,500, $1000 \mathrm{~m}$ above ground level for each day were constructed by the atmospheric model Hybrid Single-Particle Lagrangian Integrated Trajectories (HYSPLIT), version 4 [23]. Trajectories were generated according to the Preila site coordinates at angles

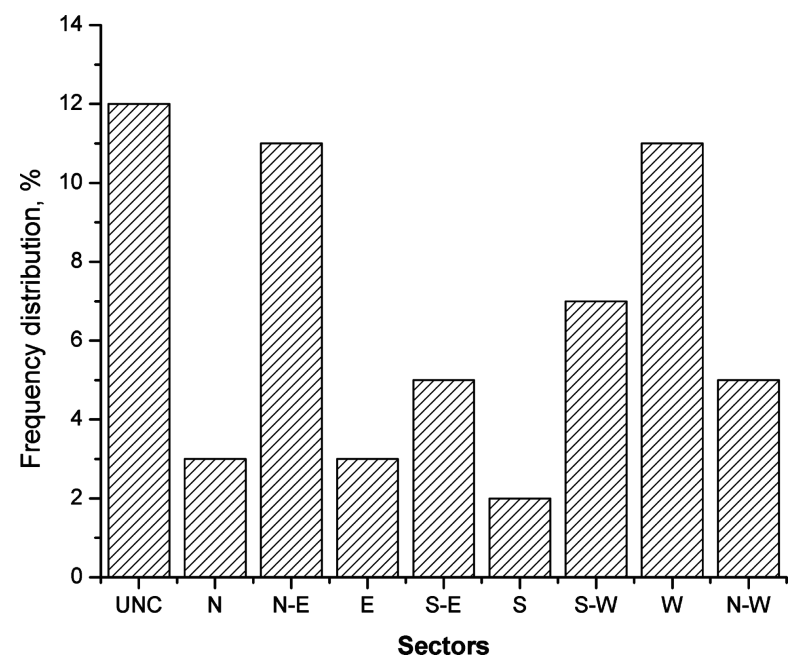

Fig. 4. Frequency (\%) of air mass transport from different sectors in Preila (March, April 2002).

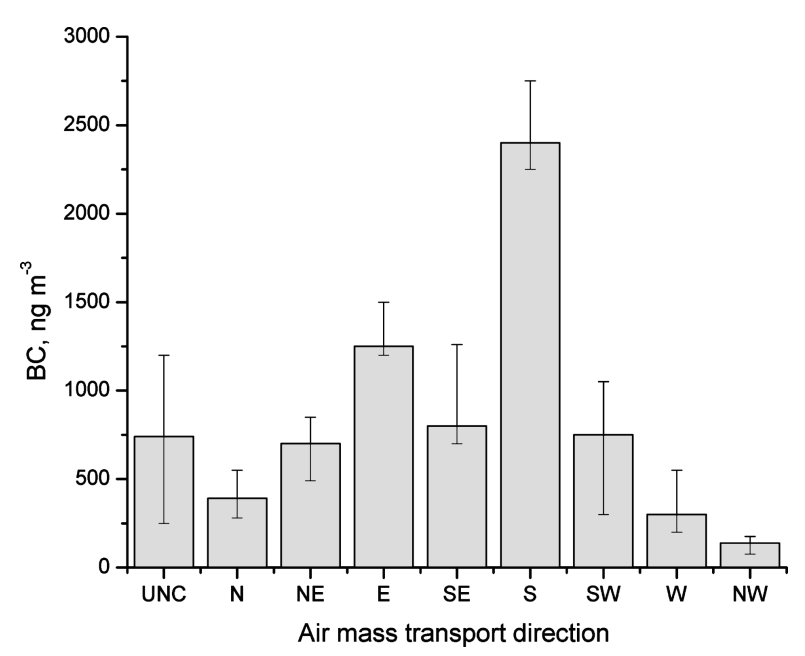

Fig. 5. Mean BC concentrations in different air masses in Preila. The presented statistics are 25 th and 75 th percentiles.

$0-360^{\circ}$ on maps and divided into 9 sectors corresponding to 8 directions measured clockwise with respect to north (N, NW, W, SW, S, SE, E, NE) and one class with unclear origin (UNC). The analysis of air masses transport direction distribution shows that the northeast $(11 \%)$, west (11\%), and south-west direction (7\%) during the study period prevailed. A large number of cases (12\%) was assigned to UNC direction (Fig. 4).

Air mass backward trajectories have been analysed to study a possible transport of $\mathrm{BC}$ from different regions to Preila. $\mathrm{BC}$ concentration in various air masses over that period varied from the average minimum value of approximately $140 \mathrm{ng} \mathrm{m}^{-3}$ to the maximum value of $2410 \mathrm{ng} \mathrm{m}^{-3}$ (Fig. 5). Based on this trajectory analysis, air masses were categorized into three classes, i. e., marine, continental, and mixed (both continental and marine). 


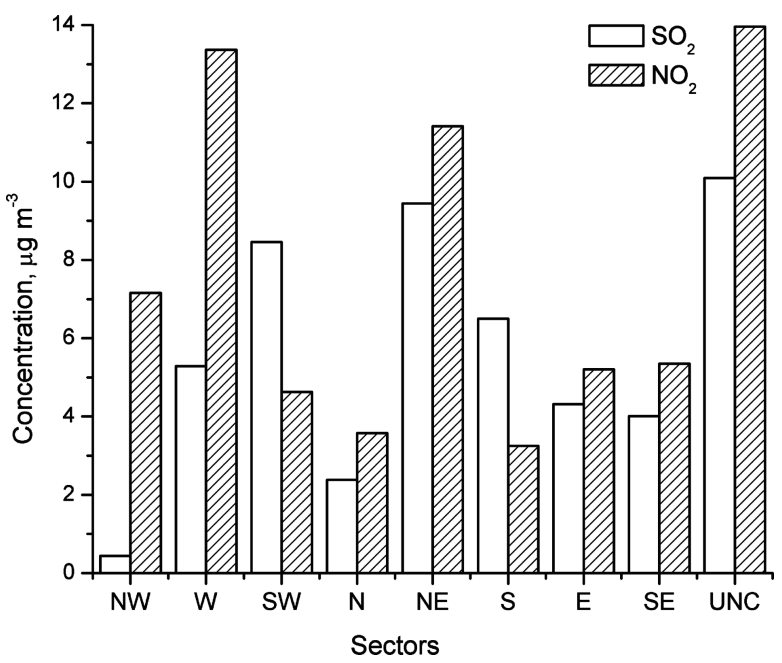

Fig. 6. Mean $\mathrm{NO}_{2}$ and $\mathrm{SO}_{2}$ concentrations in air masses transported from different sectors to the Preila site, March-April 2002.

The daily mean BC concentrations at the Preila site during the arrival of different air masses are presented in Fig. 5. The period of March to April was generally under the influence of a continental air mass, while the air mass from the sea seldom occurred. The highest average concentration was observed in continental air masses (S, E, SE) and the lowest one in marine or mixed - marine and continental $(\mathrm{N}, \mathrm{NW}, \mathrm{W})$ air masses. Air masses from neighbouring regions of Poland or sometimes those from far away places in Germany, Czech Republic might have transported continental air masses from these regions to Preila with significant average concentrations of carbonaceous particulate matter $\left(2.72 \mu \mathrm{g} \mathrm{m}^{-3}\right)$ [24]. Moreover, during this period, sometimes westerly air masses carrying marine air masses mixed with continental ones were passing nearby or across some coastal regions of Norway, Sweden, or Finland, and thus brought the continental air mixed with the marine air. The average BC concentration during this period was approximately 390 and $750 \mathrm{ng} \mathrm{m}^{-3}$ in mixed $(\mathrm{N})$ and continental (NE) air masses, respectively. Whereas during the period when only marine air masses from the Baltic Sea were transported, the average BC concentration was about $220 \mathrm{ng} \mathrm{m}^{-3}$. During the experiment, the total average $\mathrm{BC}$ concentration value from the southern directions was $2410 \mathrm{ng} \mathrm{m}^{-3}$, whereas the total average mean BC concentration value in air mass arriving from NW was $140 \mathrm{ng} \mathrm{m}^{-3}$.

Slightly higher concentrations of $\mathrm{NO}_{2}$ were related to $\mathrm{W}$ and $\mathrm{NE}$ directions and those of $\mathrm{SO}_{2}$ with $\mathrm{NE}$ and SW direction (Fig. 6). Measured concentration values of these components have distinctly shown the origin of air masses that arrived at the Preila site (marine or continental).

\subsection{Particle size distribution and $B C$}

A wide range of concentration values of various pollutants in the atmosphere are related to the geographical location, emission source, and meteorological conditions. During the analysed period, on some days the episodes of the $\mathrm{BC}$ concentration increase and decrease were observed and were chosen for analysis in more detail because these episodes could be related not only to advection of the BC aerosol but to new particle formation processes as well.

Along with the BC concentration measurements, concentrations and the size distribution of aerosol particles were measured with the spectrometer ELAS-5Mc. Due to instrumentation limitation, the smallest detected size was $10 \mathrm{~nm}$. The aerosol size distribution was plotted as contour plots for each day (as a function of time) of two months (March-April). Those events were analysed for the possible nucleation events, as described by Kulmala et al. [25]. For each day event, the growth rate was calculated graphically from the contour plots ("banana-plots"). The Preila events are characterized by a quite clear "banana" shape. An example of such plot, together with the number concentrations of each mode, which has been a nucleation event day with the growth rate of about $3.7 \mathrm{~nm} \mathrm{~h}^{-1}$, is shown in Fig. 7 . The growth rate was calculated by a special MATLAB program [26].

Figure $7(\mathrm{a}-\mathrm{c})$ shows the time evolution of aerosol particle size distribution and modal aerosol and BC concentrations during the event of 9 March 2002. There is a clear decrease of nucleation mode particles at a lower end of the detection limit $(10 \mathrm{~nm})$ due to coagulation with larger particles (Fig. 7(b), 1-3 p.m.). During the coagulation stage, the growth rate of particles increases from 3 to $5 \mathrm{~nm} \mathrm{~h}^{-1}$, being the main reason why the concentration of accumulation mode particles increased. The hourly data of carbonaceous aerosol particle concentration showed strong UV absorption at $370 \mathrm{~nm}$, which could be related to the association of soot with organics (Fig. 7(c)). The hydroscopic possibilities and the speed of water vapour absorption by the nucleation mode particles increase. During this event, new particles evidently were formed due to specific reactions, which occur over the sea at night, involving organic compounds [9]. It may be supposed that primary $\mathrm{BC}$ is emitted to the atmosphere as hydrophobic particles, eventually becoming hydrophilic by oxidation or 

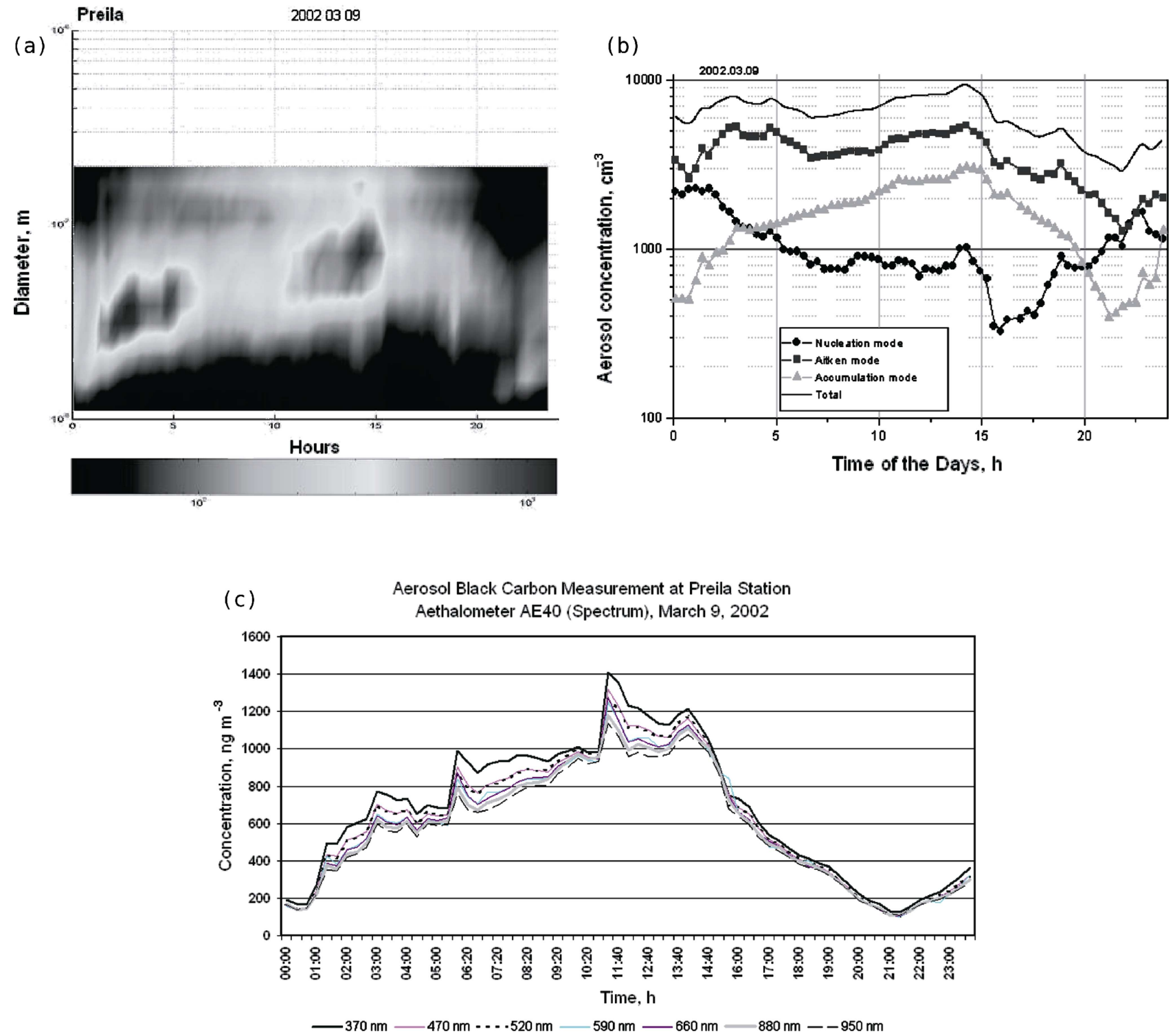

Fig. 7. (a) Time evolution of aerosol particle size distributions in Preila on 9 March 2002, (b) modal aerosol concentration, and (c) carbonaceous particle concentrations.

after coating by soluble aerosols such as sulphate and organics [27]. Consequently, at wavelengths of $370 \mathrm{~nm}$, certain kinds of organic compounds start to show strong UV absorption [28].

During the formation of a new aerosol particle event, a sharp rise of the mass concentration of carbonaceous particles was evidently caused by the advection of polluted air masses to the study site (Fig. 7(c)).

\section{6. $B C$ in different environment}

The comparison of carbonaceous aerosol particles detected directly at the highway with particles of this pollutant observed at a background site may provide information on the atmospheric fate of the traffic exhausts. Atmospheric dilution or particle aging could be observed. For this purpose, several measurement series have been carried out. Real-time black carbon concentrations were measured with an aethalometer, while particle counts were simultaneously performed with the LAS-15A $(0.3-10 \mu \mathrm{m})$ optical particle counter at the Preila site. The average diurnal cycle of the $\mathrm{BC}$ aerosol and different aerosol size number concentration at the Preila site on 7 March 2002 are shown in Figs. 8 and 9. As shown in Fig. 9, diurnal variation of 0.3, 0.32, and $0.35 \mu \mathrm{m}$ size aerosol in Preila during the experiment showed a prominently sharp nocturnal peak at around $0-5$ a.m., while $1.3,1.5$, and $2.0 \mu \mathrm{m}$ size aerosol showed the peak in the morning between $8 \mathrm{a} . \mathrm{m}$. and 12 p.m. In the morning, after the sunrise, the nocturnal boundary layer breaks lifting up the fine particles. This 


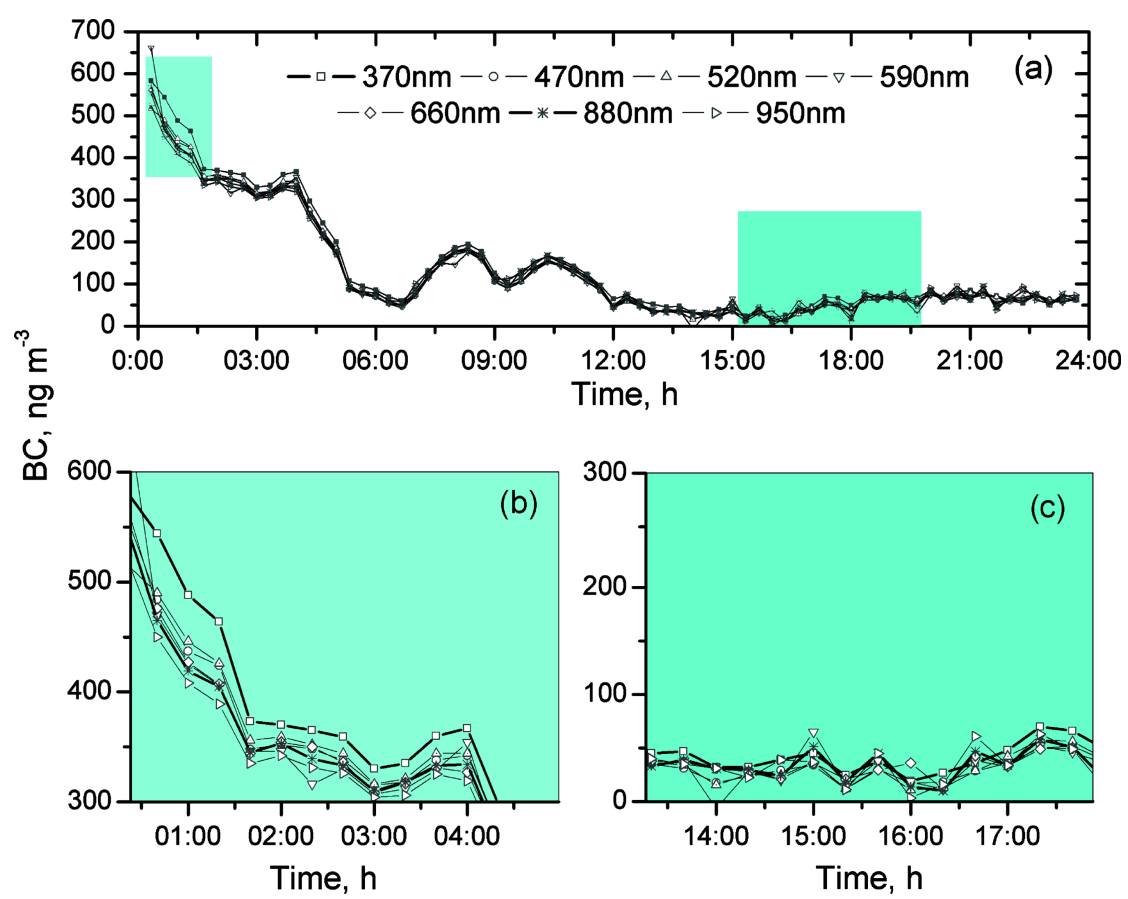

Fig. 8. (a) Diurnal variation of BC aerosol concentration measured sequentially at seven wavelengths on 7 March 2002 at the Preila site, $(b, c)$ are shaded areas from (a) on larger scale.

gives a sharp peak in the morning. Then, the concentrations continued decreasing gradually due to increased convective activity and the minimum value was reached in the afternoon.

A comparison of diurnal course of the aerosol size number concentration with $\mathrm{BC}$ aerosol particle concentration shows that the largest contributor to the fine particle mass in the atmosphere at background site has been carbon particulate matter. Moreover, during the study period all seven species of carbonaceous particles were found with a robust light absorbing organic material in aerosol (Fig. 8).

Some aerosol samples were collected in order to determine the $\mathrm{BC}$ concentration in the freshly emitted traffic exhausts. The experiment was carried out at the Vilnius-Klaipeda highway on March 2, 2002. The measurement data of the traffic exhausts of BC concentration are presented in Fig. 10. Data show that the carbonaceous aerosol particle concentration rapidly changes over time and absorption spectra depend on wavelengths. During the soot particle formation, aggregates can be produced by the collision of primary particles, which are formed by the reactive surface growth of volatile species generated during combustion [28]. It was found that soot particles in the fresh exhausts dominated in the size range of $0.1-1 \mu \mathrm{m}$.

The highest concentration of freshly exhausted aerosol containing a particular organic compound at the wavelength of $370 \mathrm{~nm}$ was about $4300 \mathrm{ng} \mathrm{m}^{-3}$, while the concentration of $\mathrm{BC}$ at the wavelength of $880 \mathrm{~nm}$ was about $3400 \mathrm{ng} \mathrm{m}^{-3}$. The experimental data showed that the contribution of concentrations of different species of carbonaceous particles in background aerosols during long transport in the atmosphere was approximately equal, and $\mathrm{BC}$ dominated in the composition of all species. Data of the emission from "fresh" traffic exhausts showed that concentrations of various species of carbonaceous aerosols for some time were different (Fig. 10).

\section{Conclusions}

The concentration of black carbon aerosol observed in Preila is dependent on the history of air masses transported over the site. Highest concentrations of black carbon were observed in continental air masses (southern transport directions), and the lowest ones in marine air masses (northern transport direction).

The relationship of black carbon with chemical species $\left(\mathrm{SO}_{2}, \mathrm{NO}_{2}, \mathrm{O}_{3}\right)$ was investigated, and it was found that the correlation between black carbon, $\mathrm{SO}_{2}$, and $\mathrm{NO}_{2}$ was positive, with a correlation coefficient of 0.44 and 0.43 , respectively, and that for $\mathrm{O}_{3}$ was negative, with a correlation coefficient from -0.30 to -0.55 .

The size distribution of the "fresh" black carbon aerosols shows that the majority of all soot types occur in the smallest size fraction range. 


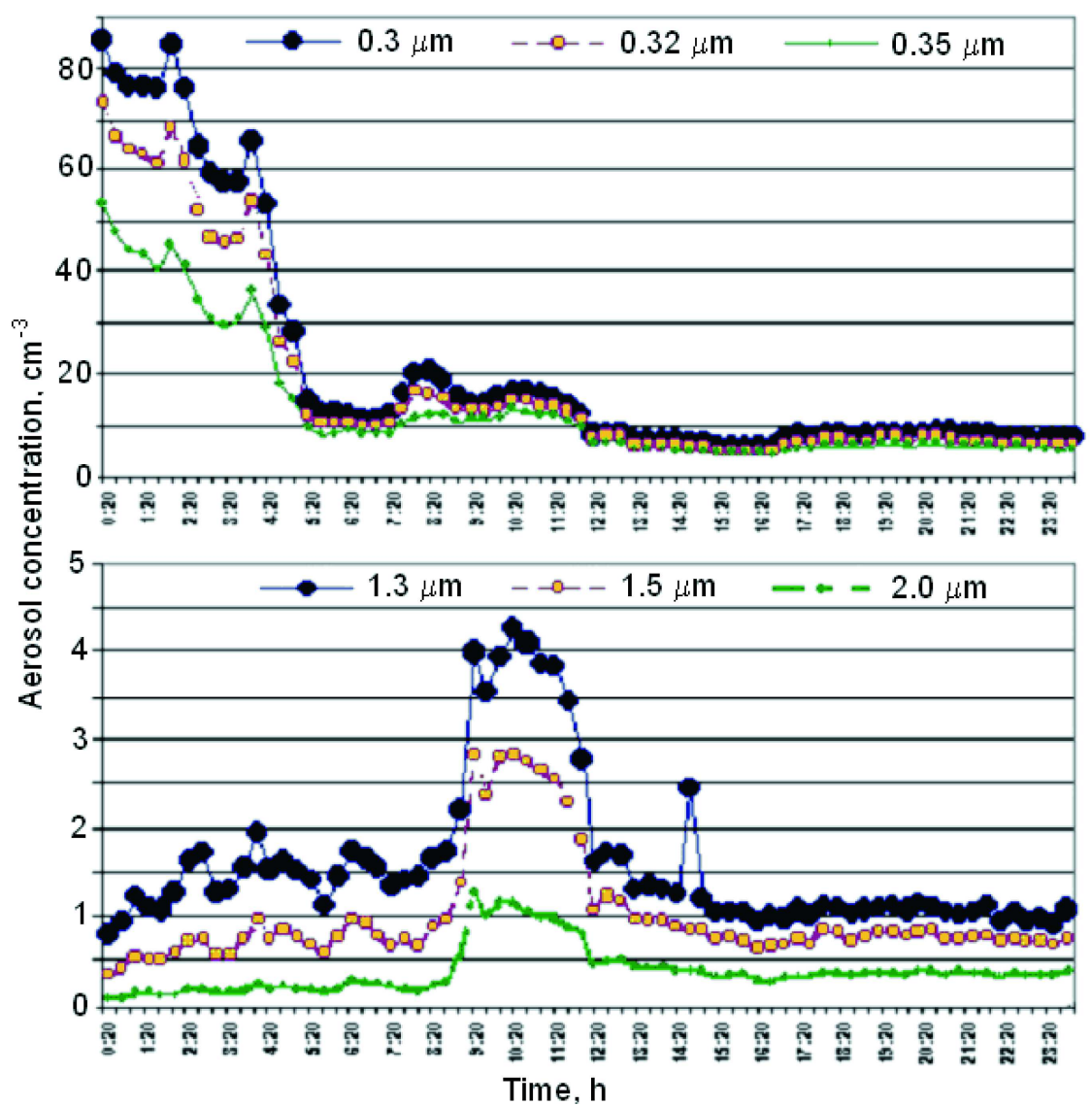

Fig. 9. Diurnal cycle of the different aerosol size number concentration variation at the Preila site on 7 March 2002.

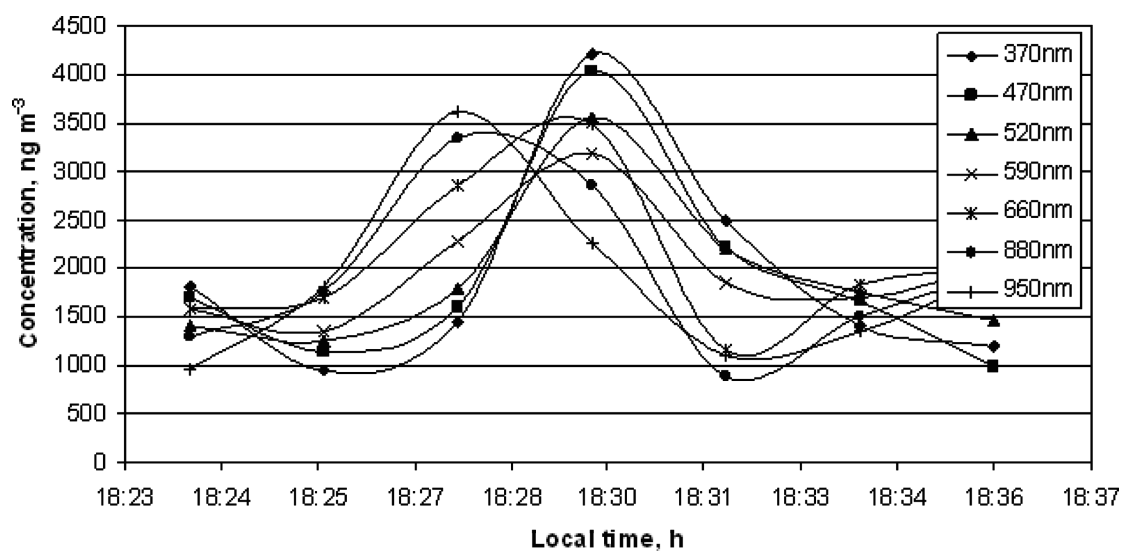

Fig. 10. Carbonaceous aerosol particle concentration at the highway Vilnius-Klaipeda on 2 March 2002.

\section{Acknowledgements}

The research was supported by the Lithuanian State Science and Studies Foundation and FP6 project EUSAAR. We thank Dr D. Šopauskienè, Dr D. Jasinevičienè (Institute of Physics, Vilnius) for providing the Preila March-April $2002\left(\mathrm{NO}_{2}, \mathrm{SO}_{2}\right)$ data. Authors are grateful to Dr A. Milukaite (Institute of Physics, Vilnius) for her comments during preparation of this paper.

\section{References}

[1] M.Z. Jacobson, Strong radiative heating due to the mixing state of black carbon in atmospheric aerosols, Nature 409 (6821), 695-697 (2001).

[2] A. Kirkevag, T. Iversen, and A. Dahlback, On radiative effects of black carbon and sulphate aerosols, Atmos. Environ. 33, 2621-2635 (1999).

[3] G.H. Andrew and G.R. Cass, Source contributions to atmospheric fine carbon particle concentrations, Atmos. Environ. 32, 3805-3825 (1998). 
[4] A. Molnar, E. Meszaros, H.C. Hansson, H. Karlsson, A. Gelencser, GY. Kiss, and Z. Krivacsy, The importance of organic and elemental carbon in the fine atmospheric aerosol particles, Atmos. Environ. 33, 27452750 (1999).

[5] R. Hitzenberger and S. Tohno, Comparison of black carbon (BC) aerosols in two urban areas - concentrations and size distributions, Atmos. Environ. 35, 21532167 (2001).

[6] M. Shaap, H.A.C. Denier Van Der Gon, A.J.H. Visschedijk, M. Van Loon, H.M. Brik, F.J. Dentener, J.P. Putaud, B. Guillaume, C. Liousse, and P.J.H. Builtjes, Anthropogenic black carbon and fine aerosol distribution over Europe, J. Geophys. Res. 109, D18207, doi: 10.1029/2003JD004330 (2004).

[7] J.N. Pitz, Formation and fate of gaseous and particulate mutagens and carcinogens in real and simulated atmospheres, Environ. Health Perspectives 47, 115-140 (1983).

[8] S. Kamm, O. Mohler, K.H. Naumann, H. Saathoff, and U. Schurath, The heterogeneous reaction of ozone with soot aerosol, Atmos. Environ. 33, 4651-4661 (1999).

[9] L. Laakso, T. Hussein, P. Aarnio, M. Komppula, V. Hiltunen, Y. Viisanen, and M. Kulmala, Diurnal and annual characteristics of particle mass and number concentrations in urban, rural and Arctic environments in Finland, Atmos. Environ. 37, 2629-2641 (2003).

[10] F. Funasaka, T. Miyazaki, T. Kawaraya, K. Tsuruho, and T. Mizuno, Characteristics of particulates and gaseous pollutants in a highway tunnel, Environ. Pollut. 102, 171-176 (1998).

[11] J.H. Seinfeld and S.N. Pandis, Atmospheric Chemistry and Physics: From Air Pollution to Climate Change (Wiley, New York, 1998).

[12] L.M. Castro, C.A. Pio, R.M. Harrison, and D.J.T. Smith, Carbonaceous aerosol in urban and rural European atmospheres: Estimation of secondary organic carbon concentrations, Atmos. Environ. 33, 2771-2781 (1999).

[13] Z. Krivacsy, A. Hoffer, Zs. Sarvari, D. Temesi, U. Baltensperger, S. Nyeki, E. Weingartner, S. Kleefeld, and S.G. Jennings, Role of organic and black carbon in the chemical composition of atmospheric aerosol at European background sites, Atmos. Environ. 35, 6231-6244 (2001).

[14] S. Koga, T. Maeda, and N. Kaneyasu, Source contributions to black carbon mass fractions in aerosol particles over the northwestern Pacific, Atmos. Environ. 42, 800-814 (2008).

[15] D. Šopauskienė and D. Jasinevičienè, Time series and trends in atmospheric concentrations of sulphur and nitrogen dioxides in Lithuania in 1981-2001, Environ. Chem. Phys. 26, 100-108 (2004).

[16] R.W. Bergstrom, P.B. Russell, and P. Hignett, The wavelenght dependence of black carbon particles: Predictions and results from the TARFOX experiment and implications for the aerosol single scattering albedo, J. Atmos. Sci. 59, 567-577 (2002).

[17] J. Sandradewi, A.S.H. Prevot, E. Weingartner, R. Schmidhauser, M. Gysel, and U. Baltensperger, A study of wood burning and traffic aerosols in an Alpine valley using a multi-wavelength Aethalometer, Atmos. Environ. 42, 101-112 (2008).

[18] V. Ulevičius, G. Mordas, and K. Plauškaitè, Nucleation events at the Preila environmental research station, Environ. Chem. Phys. 24, 38-44 (2002).

[19] R. Girgždienè, D. Šopauskienè, and A. Girgždys, The change of $\mathrm{O}_{3}, \mathrm{SO}_{2}$ and $\mathrm{NO}_{2}$ concentrations in Lithuania, Environ. Sci. Pollut. Res., Special Issue 1, 3-7 (2002).

[20] D. Šopauskienė, D. Jasinevičienè, and S. Stapčinskaitė, The effect of changes in European anthropogenic emissions on the concentrations of sulphur and nitrogen components in air and precipitation in Lithuania, Water, Air Soil Pollut. 130, 517-522 (2001).

[21] Real-time scientific measurements for over 20 years, www.mageesci.com .

[22] W. Fendel, D. Matter, H. Bursther, and A. Schmidt-Ott, Interaction between carbon or iron aerosol particles and ozone, Atmos. Environ. 29, 963-973 (1995).

[23] NOAA, www .arl.noaa.gov/ready.html.

[24] A. Milukaitè, K. Kvietkus, and I. Rimšelytė, Organic and elemental carbon in coastal aerosol of the Baltic Sea, Lithuanian J. Phys. 47, 203-210 (2007).

[25] M. Kulmala, A. Toivonen, J.M. Mäkelä, and A. Laaksonen, Analysis and growth of the nucleation mode particles observed in Boreal forest, Tellus 50B, 449-462 (1998).

[26] K. Plauškaitė, R. Kazlauskaitè, J. Andriejauskienė, and V. Ulevičius, Parametrization of new particle formation and growth at the Preila station, Lithuanian J. Phys. 45, 139-147 (2005).

[27] F. Parungo, J.F. Boatman, H. Sievering, S.W. Wilkison, B.B. Hicks, Trends in global marine cloudiness and anthropogenic sulphur, J. Climate 7, 434-440 (1994).

[28] H. Saathoff, K.H. Naumann, M. Schnaiter, W. Schock, E. Weingartner, U. Baltensperger, L. Kramer, Z. Bozoki, U. Poschl, R. Niessner, and U. Schurath, Carbon mass determinations during the AIDA soot aerosol campaign 1999, Aerosol Sci. 34, 1399-1420 (2003). 


\title{
JUODOSIOS ANGLIES AEROZOLIO DALELE்S FONINĖJE VIETOVE்JE BALTIJOS JŪROS PAKRANTÉJE
}

\author{
J. Andriejauskienè ${ }^{\mathrm{a}}$, V. Ulevičius ${ }^{\mathrm{a}}$, M. Bizjak ${ }^{\mathrm{b}}$, N. Špirkauskaité ${ }^{\mathrm{a}}, \mathrm{S}$. Byčenkiené ${ }^{\mathrm{a}}$ \\ ${ }^{a}$ Fizikos institutas, Vilnius, Lietuva \\ ${ }^{\mathrm{b}}$ Liublijanos universitetas, Liublijana, Slovenija
}

\section{Santrauka}

Atmosferoje aerozolio dalelès, sudarytos iš juodosios anglies (dar vadinamos elementine anglimi) ar organinès anglies, tiesiogiai veikia Žemès energini balansą, sugerdamos ar atspindèdamos Saulès spinduliuotę ir tuo pačiu veikdamos tiek globalinį, tiek regionini klimatą. Pateikti juodosios anglies aerozolio dalelių koncentracijų kaitos $2002 \mathrm{~m}$. kovo-balandžio mènesiais Preilos aplinkos užterštumo tyrimų stotyje tyrimai. Juodosios anglies aerozolio daleliu koncentracijos matavimai buvo atliekami etalometru A-40 Spectrum (Slovènija). Tuo pačiu metu optiniu dalelių skaitikliu (LAS-15A, Fizikos institutas, Lietuva) ir diferencinio daleliu judrumo skaitikliu (ELAS-5Mc, Fizikos institutas, Lietuva) matuota aerozolio dalelių $(0,3-10 \mu \mathrm{m})$ skaitinè koncentracija ir jų dydžių (10-200 nm) spektras. Taip pat buvo matuotos $\mathrm{NO}_{2}, \mathrm{SO}_{2}$ ir $\mathrm{O}_{3}$ koncentracijos. Taikant HYSPLIT-4 modelio metodiką skaičiuotos 24 val. atgalinès oro masių pernašos į Preilos stoti trajektorijos, nustatant oro masių priešistorę. Apie $73 \%$ išmatuotu juodosios ang- lies aerozolio daleliu koncentracijų tiriamuoju laikotarpiu buvo 0$1000 \mathrm{ng} \mathrm{m}^{-3}$ ribose ir tik $27 \%$ buvo didesnès $-1000-3000 \mathrm{ng} \mathrm{m}^{-3}$. Nustatyta, kad didžiausia juodosios anglies aerozolio daleliu koncentracija (2410 $\mathrm{ng} \mathrm{m}^{-3}$ ) Preiloje buvo vyraujant pietiniu ir pietvakarinių krypčių oro masių pernašai. Mažiausia jų koncentracija $\left(140 \mathrm{ng} \mathrm{m}^{-3}\right.$ ) buvo, kai oro masės slinko nuo Atlanto vandenyno per Baltijos jūrą ar virš Skandinavijos (Š ir ŠV krypčių). Analizė parodè, kad juodosios anglies aerozolio koncentracija buvo didesnè balandžio $\left(960 \mathrm{ng} \mathrm{m}^{-3}\right)$ nei kovo $\left(720 \mathrm{ng} \mathrm{m}^{-3}\right)$ mèn. Paros metu didesnès koncentracijos stebètos 8-11 ir 19-22 val. Nustatytas teigiamas koreliacijos ryšys tarp juodosios anglies ir $\mathrm{SO}_{2}$ bei $\mathrm{NO}_{2}$ koncentracijų kaitos, atitinkamai 0,44 ir 0,43 , ir neigiamas su ozonu kovo $(-0,30)$ ir balandžio $(-0,55)$ mèn. Juodosios anglies aerozolio dalelių dydžiu pasiskirstymo analizè ir foninèje stotyje (Preila), ir Vilniaus-Klaipèdos magistralèje (,švieži“ transporto kuro produktų išmetimai) parodè, kad dominuoja mažiausių dydžiu frakcijos. 